\title{
Women Empowerment through Self-Help Groups (SHGs) in Three Dimensions: An Empirical Study of Rural Andhra Pradesh
}

\author{
K. Harika ${ }^{1 *}$, K. Raviteja ${ }^{2}$ and V. Nagaraju ${ }^{3}$ \\ ${ }^{1}$ Asst. Professor (C), Department of Economics, Adikavi Nannaya University, MSN Campus, Kakinada-533005, India \\ ${ }^{2}$ Lecturer in Political Science, The Hindu College, Machilipatnam, Andhra Pradesh - 521001, India \\ ${ }^{3}$ Research Scholar, Department of Economics, Acharya Nagarjuna University, Guntur - 522 510, India \\ *Corresponding author: harikak65@gmail.com
}

Received: 22-08-2020

Revised: 20-11-2020

Accepted: 06-12-2020

\begin{abstract}
In the present paper an attempt has made to study women empowerment through SHGs in three dimensions in rural Andhra Pradesh. Among all the 13 Districts of Andhra Pradesh, three districts of North Coastal Andhra Pradesh were selected as sample area for the study. Multi stage random sampling method is used for selecting sample units. The selection process carried out in four stages; relating to districts, mandals, villages and households. The primary data collected from 600 households were selected from the 24 villages of the 6 selected mandals from all the 3 North Coastal Districts of Andhra Pradesh. The opinion of SHG members collected with Likert's five point scaling technique on 10 indicators for each to dimension of Social, Economic and Political issues relating to empowerment. To find out whether the participation in SHG programs has led to empower or not, Empowerment Index is calculated separately for Old Self-Help Groups (OSHGs) and New Self-Help Groups (NSHGs) and made comparison. Descriptive analysis along with Chi-square test, F-test and Z-test are used for fruitful inferences. The Results revealed that the OSHG members are observed better empowered when compared to NSHG in socio, economic and political dimensions. Further the study confirmed that as member in SHGs for long time helps to improve the women empowerment.
\end{abstract}

Keywords: Self-Help Groups, Women Empowerment and Index

Although the position of women has improved over the last 25 years, societal and structural barriers continue to limit the opportunities for gender equality in 'substantive freedoms' such as employment, health care, and democratic freedoms (Sen, 2001). Furthermore, the relationship between economic growth and empowerment is probably too weak to be self-sustaining (Duflo, 2012). Thus, it remains necessary to support policies and development programmes that stimulate gender equality and women's empowerment directly. Self-help group (SHG) programmes are among the most popular development interventions to stimulate women's empowerment, particularly in South Asia (Jakimow and Kilby, 2006). It is estimated that close to 200 million people across the developing world have found their way into a self-help group (SHG) by 2017. In majority, these SHG members are women, as the SHG

How to cite this article: Harika, K., Raviteja, K. and Nagaraju, V. (2020) Women Empowerment through Self-Help Groups (SHGs) in Three Dimensions: An Empirical Study of Rural Andhra Pradesh. Int. J. Soc. Sci., 9(04): 263-271.

Source of Support: None; Conflict of Interest: None 
model is believed to be particularly appropriate for working towards women empowerment based on the idea that collective action (Alemu et al. 2018). Recently, Brody et al. (2017) focused on the impact of women's self-help groups (SHGs) on women's economic, social, psychological, and political empowerment, the study reports positive impacts. However, although several impact evaluations have estimated the impact of women's SHGs. In the present paper an attempt has made to examine the Social, Economic and Political empowerment of members through SHGs in rural Andhra Pradesh.

\section{Review of Literature}

Pathak (1992) reported that SHG being comprised of group of persons, gets empowered to solve most of their problems of non- financial nature like raw materials, inputs supply, marketing, better adoption of technology, education and training for realizing the human potential for development. Girija (1995) stated that the group provides the women a base for self-employment and empowerment through group dynamics. The peer pressure on group members has ensured proper utilization of credit and repayment of loans, savings provided self-insurance and self-assurance to the group members. Nanda (1999) conducted impact studies of self-help and found that the most outstanding impact of the linkage programme could be the socio-economic empowerment of the poor more particularly the women. Dadhich (2001) stated that effective implementation of micro-finance can be a means not only to alleviate poverty and empower woman but also be a viable economic and financial proportion. Savitha (2004) reported that economic empowerment was high for agricultural laborers followed by small farmers and landless farmers through SHGs. Prasad (2006) stated that the micro- credit mechanism of self-help groups has facilitated socio-economic empowerment of weaker sections including women folk. Maurya (2011) provided some perspective to elaborate the empowerment of women through SHGs. Kumar (2013) attempted to understand the impact of SHG programs on women empowerment. They have significant influence on the choices that their children make. Husain et al. (2014) attempted to test the significance of the programme effect of SHGs by comparing empowerment levels of newly inducted and older members of SHGs. Garikipati et al. (2016) reviewed the claim that impact of SHGs in promotion gender equality. The study reports positive impact. Sami (2017) measured the impact of SHG programs on women empowerment in five districts of North India and confirmed that there is a significant impact of microfinance on women empowerment.

\section{Frame work}

Empowerment is an intrinsic quality of a person, which cannot be bestowed by a third party. It is considered that an empowered person's behavior undergoes a change. In a nutshell, empowerment is a process which enables one to gain power, authority and influence over others. In the literature published on the subject, the empowerment is considered to be matching with the following traits (Bansal, 2010).

* Having decision-making power of one's own

* Having access to information and resources for taking proper decision

* Having a range of options from which one can make choices

* Ability to exercise assertiveness in collective decision-making

* Having positive thinking about the ability to make change

* Ability to learn skills for improving one's personal or group power

* Ability to change others' perceptions by democratic means

* Involving in the growth process

Empowerment helps the person concerned to exploit the economic environment in increasing the productivity of self, family and the society. In a policy research report, World Bank (2001) identified both gender equality and women empowerment as development objectives and means to promote growth, reduce poverty and support better governance. In the literature available on women empowerment, some of the concepts like gender equality, female autonomy or women status etc. are referring to as either similar or different concepts. 
Table 1: JSI Domains of Empowerment

\begin{tabular}{|c|c|c|}
\hline S1. No. & Domain & Expressions \\
\hline 1 & Sense of Self \& vision of a future & $\begin{array}{l}\text { Assertiveness, plans for the future, future-oriented actions, relative freedom from threat } \\
\text { of physical violence, awareness of own problems and options, actions indicating sense of } \\
\text { security. }\end{array}$ \\
\hline 2 & Mobility \& visibility & $\begin{array}{l}\text { Activities outside of the home, relative freedom from harassment in public spaces, } \\
\text { interaction with men. }\end{array}$ \\
\hline 3 & Economic Security & $\begin{array}{l}\text { Property ownership, new skills and knowledge and increased income, engaged in new/ } \\
\text { non-traditional types of work. }\end{array}$ \\
\hline 5 & $\begin{array}{l}\text { Ability to interact effectively in } \\
\text { the public sphere }\end{array}$ & $\begin{array}{l}\text { Awareness of legal status and services available, ability to get access to social services, } \\
\text { political awareness, participation in credit program, provider of service in community. }\end{array}$ \\
\hline 6 & $\begin{array}{l}\text { Participation in non-family } \\
\text { groups }\end{array}$ & $\begin{array}{l}\text { Identified as a person outside the family, forum for creating sense of solidarity with } \\
\text { other women, self-expression and articulation of problems, participating in a group with } \\
\text { autonomous structure. }\end{array}$ \\
\hline
\end{tabular}

Source: John Snow Inc. (JSI), 1990.

One can judge empowerment through indicators. These indicators can be given values, based on the judgment of the researcher. Some of the studies assign weights to the indicators, which are mostly arbitrary. However, there cannot be any measure of empowerment because the nature of the concept is such that it is multifaceted concept which is not readily quantifiable. It can be said that empowerment is context and region specific which implies that there cannot be some standard indicators of women empowerment, applicable to all times and places. So, the measurement of empowerment through indicators can only be in a given socio-economic and political context where an intervention is made. There have been several efforts to devise indicators of empowerment. The table 1 shows the six domains of empowerment as suggested by the John Snow (Mehta \& Sharma, 2014).

Mostly, indicators of empowerment are proxy variables. During the field survey a number of questions were asked to capture the process of decision-making, control, choice etc. Such questions are observed as most effective representations of the process of empowerment. The indicators of empowerment based on field survey questions are specific and relevant within a particular social context. The present study takes into consideration 10 indicators for each to measure Social,
Economic and Political empowerment. Table 2 shows these 30 indicators of women empowerment taken into consideration for the present study.

Table 2: Indicators of Empowerment

\begin{tabular}{ll}
\hline Domain & Indicators \\
\hline & 1. Self-confidence \\
2. Reduction in alcoholic habits \\
3. Attitude towards the education of \\
Socio-cultural & 4aughters \\
Empowerment & 5. Mttitude towards the education of sons \\
& 6. Access to markets \\
& 7. Adoption of small family norm \\
& 8. Discontinuation of early marriages \\
& 9. Reduction in domestic violence \\
10. Decision-making in the family
\end{tabular}




\begin{tabular}{ll}
\hline & 1. Access to political leaders \\
& 2. Access to M.P. and M.L.A \\
3. Improvement in political awareness \\
4. Improvement in voting \\
Eolitical & 5. Participation in election \\
& 6. Interest in political news \\
& 7. Discussion of political issues \\
8. Participation in government programmes \\
9. Ability to meet government officials \\
10. Ability to meet non-government officials
\end{tabular}

Source: Author Elaborations.

\section{Methodology}

The present study aims to examine the Social, Economic and Political empowerment through SHGs from rural areas in Andhra Pradesh. Among the 13 Districts of Andhra Pradesh, all the three districts of North Coastal Andhra Pradesh namely Visakhapatnam (VSKP), Vizianagaram (VZM) and Srikakulam (SKLM) are selected for the study. Multi stage random sampling method is used in the present study for selecting sample units. The selection process was carried out in four stages; i.e., relating to districts, mandals, villages and households. As a whole a number of 600 households were selected from the 24 villages of the 6 selected mandals from all the 3 North Coastal Districts of Andhra Pradesh. In all, 600 SHG households were selected for the study. While 300 members from old Self-Help Groups (OSHG) and 300 members from New Self-Help Groups (NSHG). For selecting OSHG, the SHGs who have completed more than 8 years membership and for selecting NSHG, the SHGs having a membership of less than 5 years is considered. Primary data were collected from the members of SHGs using well-structured questionnaire. The members of OSHGs were treated as treatment group and members of NSHGs as control group. The opinion of SHG members collected with Likert's five point scaling technique. To find out whether the participation in SHG programs has led to empower the members or not, Social Empowerment Index, Economic Empowerment Index and Political Empowerment Index are calculated. Descriptive analysis along with Chi-square test, F-test and Z-test are used for fruitful inferences.

\section{RESULTS AND DISCUSSION}

\section{Social Empowerment}

According to social empowerment index, the highest per cent were belongs to high empowered group followed by less empowered, medium empowered and very high empowered. In the case of OSGHs, equal per cent of respondents were empowered very high and high. In the case of NSHGs, the maximum respondents were high empowered followed by less empowered and medium empowered. The result of Chi-Square is revealing that there is an association between level of social empowerment and being as a SHG member for long time as the calculated statistical value is significant in Visakhapatnam and Srikakulam Districts (Table 3).

Table 3: Distribution of Respondents by Level of Social Empowerment

\begin{tabular}{|c|c|c|c|c|}
\hline $\begin{array}{l}\text { Level of } \\
\text { Empowerment }\end{array}$ & OSHG & NSHG & ALL & $\chi^{2}$ \\
\hline \multicolumn{5}{|c|}{ VSKP } \\
\hline Less Empowered & $12(12.0)$ & $23(23.0)$ & 35 (17.5) & \\
\hline $\begin{array}{l}\text { Medium } \\
\text { Empowered }\end{array}$ & $18(18.0)$ & $29(29.0)$ & $47(23.5)$ & $14.066^{*}$ \\
\hline High Empowered & $32(32.0)$ & $31(31.0)$ & $63(31.5)$ & $(0.003)$ \\
\hline $\begin{array}{l}\text { Very High } \\
\text { Empowered }\end{array}$ & $38(38.0)$ & $17(17.0)$ & $55(27.5)$ & \\
\hline Total & $100(100.0)$ & $100(100.0)$ & $200(100.0)$ & \\
\hline \multicolumn{5}{|c|}{ VZM } \\
\hline Less Empowered & $33(33.0)$ & $42(42.0)$ & $75(37.5)$ & \\
\hline $\begin{array}{l}\text { Medium } \\
\text { Empowered }\end{array}$ & $26(26.0)$ & $27(27.0)$ & $53(26.5)$ & 5.266 \\
\hline High Empowered & $24(24.0)$ & $24(24.0)$ & $48(24.0)$ & $(0.153)$ \\
\hline $\begin{array}{l}\text { Very High } \\
\text { Empowered }\end{array}$ & 17(17.0) & $7(7.0)$ & $24(12.0)$ & \\
\hline Total & $100(100.0)$ & $100(100.0)$ & $200(100.0)$ & \\
\hline \multicolumn{5}{|c|}{ SKLM } \\
\hline Less Empowered & $32(32.0)$ & $20(20.0)$ & $52(26.0)$ & \\
\hline $\begin{array}{l}\text { Medium } \\
\text { Empowered }\end{array}$ & $25(25.0)$ & $18(18.0)$ & $43(21.5)$ & $7.360^{*}$ \\
\hline High Empowered & $21(21.0)$ & $31(31.0)$ & $52(26.0)$ & $(0.061)$ \\
\hline $\begin{array}{l}\text { Very High } \\
\text { Empowered }\end{array}$ & $22(22.0)$ & $31(31.0)$ & $53(26.5)$ & \\
\hline Total & $100(100.0)$ & $100(100.0)$ & $200(100.0)$ & \\
\hline
\end{tabular}




\begin{tabular}{|c|c|c|c|c|}
\hline \multicolumn{5}{|c|}{ Total } \\
\hline Less Empowered & $77(25.7)$ & $85(28.3)$ & $162(27.0)$ & \\
\hline $\begin{array}{l}\text { Medium } \\
\text { Empowered }\end{array}$ & $69(23.0)$ & $74(24.7)$ & $143(23.8)$ & 4.733 \\
\hline High Empowered & $77(25.7)$ & $86(28.7)$ & $163(27.2)$ & $(0.192)$ \\
\hline $\begin{array}{l}\text { Very High } \\
\text { Empowered }\end{array}$ & $77(25.7)$ & $55(18.3)$ & $132(22.0)$ & \\
\hline Total & 300(100.0) & $300(100.0)$ & $600(100.0)$ & \\
\hline
\end{tabular}

Source: Computed from primary data.

Note: Chi-square values are significant if p-values less than 0.10 .

An average of score social empowerment index for OSHGs was 0.623 while NSHG was 0.605 , it can be reveals that the OSHGs observed better empowered when compared to NSHGs. The similar kind of pattern has been observed in Visakhapatnam and Vizianagaram districts whereas in Srikakulam district on contrary the NSHGs observed better empowered when compared to OSHGs. The measure of standard deviation was used to observe the homogeneity of the sample respondents of the OSHG and NSHG households. The lower the value of standard deviation indicates the higher homogeneity and vice versa. In the case of NSHG respondents have lower standard deviation when compared to OSHG respondents thus shows that the NSHG respondents were having higher homogeneity than OSHG respondents. The results of f-test and z-test disclosed that there were no significant mean variations in social empowerment between OSHGs and NSHGs in sample area (Table $3 \& 4$ ).

Table 4: Descriptive Statistics of Social Empowerment

\begin{tabular}{llllllllll}
\hline District & AREA & N & Mean & SD & SEM & Range & Variance & Minimum & Maximum \\
\hline \multirow{3}{*}{ VSKP } & OSHG & 100 & 0.693 & 0.149 & 0.015 & 0.634 & 0.022 & 0.333 & 0.967 \\
& NSHG & 100 & 0.615 & 0.156 & 0.016 & 0.767 & 0.024 & 0.233 & 1.000 \\
& Total & 200 & 0.654 & 0.157 & 0.011 & 0.767 & 0.025 & 0.233 & 1.000 \\
& OSHG & 100 & 0.590 & 0.170 & 0.017 & 0.900 & 0.029 & 0.067 & 0.967 \\
VZM & NSHG & 100 & 0.543 & 0.152 & 0.015 & 0.867 & 0.023 & 0.033 & 0.900 \\
& Total & 200 & 0.566 & 0.163 & 0.012 & 0.934 & 0.026 & 0.033 & 0.967 \\
\multirow{3}{*}{ SKLM } & OSHG & 100 & 0.587 & 0.206 & 0.021 & 0.867 & 0.042 & 0.133 & 1.000 \\
& NSHG & 100 & 0.657 & 0.151 & 0.015 & 0.733 & 0.023 & 0.267 & 1.000 \\
& Total & 200 & 0.622 & 0.183 & 0.013 & 0.867 & 0.034 & 0.133 & 1.000 \\
& OSHG & 300 & 0.623 & 0.183 & 0.011 & 0.933 & 0.033 & 0.067 & 1.000 \\
& NSHG & 300 & 0.605 & 0.159 & 0.009 & 0.967 & 0.025 & 0.033 & 1.000 \\
& Total & 600 & 0.614 & 0.172 & 0.007 & 0.967 & 0.029 & 0.033 & 1.000 \\
\hline
\end{tabular}

Source: Computed from primary data.

$S D=$ Standard Deviation $\&$ SEM $=$ Standard Error of Mean

Table 5: Social Empowerment differences between OSHG and NSHG Households

\begin{tabular}{|c|c|c|c|c|}
\hline Measures & VSKP & VZM & SKLM & Total \\
\hline \multicolumn{5}{|c|}{ Panel A: ANOVA Test } \\
\hline \multicolumn{5}{|c|}{$\mathrm{H}_{0}$ :Mean empowerment between OSHG and NSHG is not different } \\
\hline F-statistics & $13.097^{*}$ & $4.301^{*}$ & $7.472^{*}$ & 1.754 \\
\hline p-value & 0.000 & 0.039 & 0.007 & 0.186 \\
\hline Inference & Rejected $\mathrm{H}_{0}$ & Rejected $\mathrm{H}_{0}$ & Rejected $\mathrm{H}_{0}$ & Accepted $\mathrm{H}_{0}$ \\
\hline \multicolumn{5}{|c|}{ Panel B: Z Test } \\
\hline \multicolumn{5}{|c|}{$\mathrm{H}_{0}$ : Mean difference of empowerment between OSHG and NSHG is same } \\
\hline Z-statistics & $3.619^{*}$ & $2.074^{*}$ & $2.733^{*}$ & 1.324 \\
\hline p-value & 0.000 & 0.039 & 0.007 & 0.186 \\
\hline Inference & Rejected $\mathrm{H}_{0}$ & Rejected $\mathrm{H}_{0}$ & Rejected $\mathrm{H}_{0}$ & Accepted $\mathrm{H}_{0}$ \\
\hline
\end{tabular}

Source: Computed from primary data.

Note: Test values are significant if p-values less than 0.10 . 


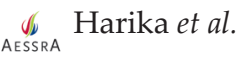

\section{Empowerment Index}

The economic empowerment index disclose that the highest per cent of respondents were belongs to less empowered followed by very high empowered and high empowered. In the case of OSGHs, the maximum respondents were less empowered followed by very high empowered and high empowered. In the case of NSHGs, majority of respondents were less empowered followed by high empowered and medium empowered. The result of Chi-Square is revealing that there is an association between level of economic empowerment and being as a SHG member for long time as the calculated test values are significant in Visakhapatnam and Srikakulam Districts (Table 6).

Table 6: Level of Economic Empowerment

\begin{tabular}{|c|c|c|c|c|}
\hline $\begin{array}{l}\text { Level of } \\
\text { Empowerment }\end{array}$ & OSHG & NSHG & ALL & $\chi^{2}$ \\
\hline \multicolumn{5}{|c|}{ VSKP } \\
\hline Less Empowered & 11(11.0) & $23(23.0)$ & $34(17.0)$ & \\
\hline $\begin{array}{l}\text { Medium } \\
\text { Empowered }\end{array}$ & $20(20.0)$ & $25(25.0)$ & $45(22.5)$ & $8.205^{*}$ \\
\hline High Empowered & $32(32.0)$ & $29(29.0)$ & $61(30.5)$ & $(0.042)$ \\
\hline $\begin{array}{l}\text { Very High } \\
\text { Empowered }\end{array}$ & $37(37.0)$ & $23(23.0)$ & $60(30.0)$ & \\
\hline Total & $100(100.0)$ & $100(100.0)$ & $200(100.0)$ & \\
\hline \multicolumn{5}{|c|}{ VZM } \\
\hline Less Empowered & $40(40.0)$ & $46(46.0)$ & $86(43.0)$ & \\
\hline $\begin{array}{l}\text { Medium } \\
\text { Empowered }\end{array}$ & 19(19.0) & $24(24.0)$ & $43(21.5)$ & 3.713 \\
\hline High Empowered & $21(21.0)$ & 19(19.0) & $40(20.0)$ & $(0.294)$ \\
\hline $\begin{array}{l}\text { Very High } \\
\text { Empowered }\end{array}$ & $20(20.0)$ & $11(11.0)$ & $31(15.5)$ & \\
\hline Total & $100(100.0)$ & $100(100.0)$ & $200(100.0)$ & \\
\hline \multicolumn{5}{|c|}{ SKLM } \\
\hline Less Empowered & $42(42.0)$ & 19(19.0) & $61(30.5)$ & \\
\hline $\begin{array}{l}\text { Medium } \\
\text { Empowered }\end{array}$ & $18(18.0)$ & $21(21.0)$ & $39(19.5)$ & $14.00^{*}$ \\
\hline High Empowered & $15(15.0)$ & $29(29.0)$ & $44(22.0)$ & $(0.003)$ \\
\hline $\begin{array}{l}\text { Very High } \\
\text { Empowered }\end{array}$ & $25(25.0)$ & $31(31.0)$ & $56(28.0)$ & \\
\hline Total & $100(100.0)$ & $100(100.0)$ & $200(100.0)$ & \\
\hline
\end{tabular}

\begin{tabular}{|c|c|c|c|c|}
\hline \multicolumn{5}{|c|}{ Total } \\
\hline Less Empowered & $93(31.0)$ & $88(29.3)$ & $181(30.2)$ & \\
\hline $\begin{array}{l}\text { Medium } \\
\text { Empowered }\end{array}$ & $57(19.0)$ & $70(23.3)$ & $127(21.2)$ & 3.993 \\
\hline High Empowered & $68(22.7)$ & $77(25.7)$ & $145(24.2)$ & $(0.232)$ \\
\hline $\begin{array}{l}\text { Very High } \\
\text { Empowered }\end{array}$ & $82(27.3)$ & 65(21.7) & $147(24.5)$ & \\
\hline Total & $300(100.0)$ & $300(100.0)$ & $600(100.0)$ & \\
\hline
\end{tabular}

Source: Computed from primary data.

Note: Chi-square values are significant if p-values less than 0.10 .

Regarding descriptive statistics for economic empowerment index, the study shows that an average score economic empowerment index for OSHGs was 0.605 while NSHG was 0.599 the mean values of index disclose that the OSHGs observed better economic empowered when compared to NSHGs. the case of OSHG respondents have lower standard deviation when compared to NSHG respondents thus shows that the OSHG respondents were having higher homogeneity than NSHG respondents. Further, the study can be observed that there were mean differences of economic empowerment index between OSGHs and NSHGs in three sampled districts. The results of f-test and z-test disclosed that there were mean variations in economic empowerment between OSHGs and NSHGs but nit significant in sample area (Table $7 \& 8$ ).

\section{Political Empowerment}

More numbers of respondents were belongs to politically less empowered group followed by high empowered, very high empowered and medium empowered. In the case of OSGHs, the highest per cent of respondents were less empowered followed by very high empowered and high empowered. In the case of NSHGs, the maximum respondents were less empowered followed by high empowered and medium empowered. The result of ChiSquare is revealing that there is no association between level of political empowerment and being as a SHG member for long time as the calculated statistical values are not significant in Vizianagaram and Srikakulam Districts while there is an association between level of political empowerment and being as a SHG member for long time as the calculated statistical value is significant in Visakhapatnam District (Table 9). 
Women Empowerment through Self-Help Groups (SHGs) in Three Dimensions

Table 7: Descriptive Statistics of Economic Empowerment

\begin{tabular}{llllllllll}
\hline District & AREA & N & Mean & SD & SEM & Range & Variance & Minimum & Maximum \\
\hline VSKP & OSHG & 100 & 0.674 & 0.114 & 0.011 & 0.533 & 0.013 & 0.400 & 0.933 \\
& NSHG & 100 & 0.625 & 0.136 & 0.014 & 0.633 & 0.018 & 0.300 & 0.933 \\
& Total & 200 & 0.650 & 0.127 & 0.009 & 0.633 & 0.016 & 0.300 & 0.933 \\
\multirow{2}{*}{ VZM } & OSHG & 100 & 0.565 & 0.156 & 0.016 & 0.700 & 0.024 & 0.167 & 0.867 \\
& NSHG & 100 & 0.531 & 0.158 & 0.016 & 0.767 & 0.025 & 0.100 & 0.867 \\
& Total & 200 & 0.548 & 0.158 & 0.011 & 0.767 & 0.025 & 0.100 & 0.867 \\
\multirow{5}{*}{ SKLM } & OSHG & 100 & 0.575 & 0.180 & 0.018 & 0.833 & 0.033 & 0.167 & 1.000 \\
& NSHG & 100 & 0.640 & 0.145 & 0.014 & 0.700 & 0.021 & 0.300 & 1.000 \\
\multirow{5}{*}{ Total } & Total & 200 & 0.607 & 0.166 & 0.012 & 0.833 & 0.028 & 0.167 & 1.000 \\
& OSHG & 300 & 0.605 & 0.160 & 0.009 & 0.833 & 0.026 & 0.167 & 1.000 \\
& NSHG & 300 & 0.599 & 0.154 & 0.009 & 0.900 & 0.024 & 0.100 & 1.000 \\
\end{tabular}

Source: Computed from primary data.

$S D=$ Standard Deviation $\mathcal{E} S E M=$ Standard Error of Mean

Table 8: Economic Empowerment differences between OSHG and NSHG Households

\begin{tabular}{|c|c|c|c|c|}
\hline Measures & VSKP & VZM & SKLM & Total \\
\hline \multicolumn{5}{|c|}{ Panel A: ANOVA Test } \\
\hline \multicolumn{5}{|c|}{$\mathrm{H}_{0}$ : Mean empowerment between OSHG and NSHG is not different } \\
\hline F-statistics & $7.630^{*}$ & 2.387 & $7.972^{*}$ & 0.219 \\
\hline p-value & 0.006 & 0.124 & 0.005 & 0.640 \\
\hline Inference & Rejected $\mathrm{H}_{0}$ & Accepted $\mathrm{H}_{0}$ & Rejected $\mathrm{H}_{0}$ & Accepted $\mathrm{H}_{0}$ \\
\hline \multicolumn{5}{|c|}{ Panel B: Z Test } \\
\hline \multicolumn{5}{|c|}{$\mathrm{H}_{0}$ : Mean difference of empowerment between OSHG and NSHG is same } \\
\hline Z-statistics & $2.762^{*}$ & 1.545 & $2.823^{*}$ & 0.468 \\
\hline p-value & 0.006 & 0.124 & 0.005 & 0.640 \\
\hline Inference & Rejected $\mathrm{H}_{0}$ & Accepted $\mathrm{H}_{0}$ & Rejected $\mathrm{H}_{0}$ & Accepted $\mathrm{H}_{0}$ \\
\hline
\end{tabular}

Source: Computed from primary data.

Note: Test values are significant if $p$-values less than 0.10 .

Table 9: Level of Political Empowerment

\begin{tabular}{|c|c|c|c|c|}
\hline Level of Empowerment & OSHG & NSHG & ALL & $\chi^{2}$ \\
\hline \multicolumn{5}{|c|}{ VSKP } \\
\hline Less Empowered & $17(17.0)$ & $28(28.0)$ & $45(22.5)$ & \multirow[b]{2}{*}{$7.614^{*}$} \\
\hline Medium Empowered & $18(18.0)$ & $25(25.0)$ & $43(21.5)$ & \\
\hline High Empowered & $30(30.0)$ & $26(26.0)$ & $56(28.0)$ & \multirow{2}{*}{$(0.055)$} \\
\hline Very High Empowered & $35(35.0)$ & $21(21.0)$ & $56(28.0)$ & \\
\hline Total & $100(100.0)$ & $100(100.0)$ & $200(100.0)$ & \\
\hline \multicolumn{5}{|c|}{ VZM } \\
\hline Less Empowered & $33(33.0)$ & $45(45.0)$ & $78(39.0)$ & \multirow[b]{2}{*}{5.536} \\
\hline Medium Empowered & $23(23.0)$ & $23(23.0)$ & $46(23.0)$ & \\
\hline High Empowered & $22(22.0)$ & $21(21.0)$ & $43(21.5)$ & \multirow[t]{2}{*}{$(0.136)$} \\
\hline Very High Empowered & $22(22.0)$ & $11(11.0)$ & $33(16.5)$ & \\
\hline Total & $100(100.0)$ & $100(100.0)$ & $200(100.0)$ & \\
\hline
\end{tabular}




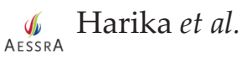

\begin{tabular}{|c|c|c|c|c|}
\hline \multicolumn{5}{|c|}{ SKLM } \\
\hline Less Empowered & $40(40.0)$ & $25(25.0)$ & $65(32.5)$ & 6.051 \\
\hline High Empowered & $23(23.0)$ & $28(28.0)$ & $51(25.5)$ & $(0.109)$ \\
\hline Total & $100(100.0)$ & $100(100.0)$ & $200(100.0)$ & \\
\hline \multicolumn{5}{|c|}{ Total } \\
\hline Less Empowered & $90(30.0)$ & $98(32.7)$ & $188(31.3)$ & $6.639^{*}$ \\
\hline High Empowered & $75(25.0)$ & $75(25.0)$ & $150(25.0)$ & \multirow[t]{2}{*}{$(0.084)$} \\
\hline Very High Empowered & $79(26.3)$ & $55(18.3)$ & $134(22.3)$ & \\
\hline Total & $300(100.0)$ & $300(100.0)$ & $600(100.0)$ & \\
\hline
\end{tabular}

Source: Computed from primary data.

Note: Chi-square values significant if p-values less than 0.10 .

Table 10: Descriptive Statistics of Political Empowerment

\begin{tabular}{|c|c|c|c|c|c|c|c|c|c|}
\hline District & AREA & $\mathbf{N}$ & Mean & SD & SEM & Range & Variance & Minimum & Maximum \\
\hline \multirow[t]{2}{*}{ VSKP } & OSHG & 100 & 0.667 & 0.143 & 0.014 & 0.634 & 0.020 & 0.333 & 0.967 \\
\hline & Total & 200 & 0.636 & 0.146 & 0.010 & 0.800 & 0.021 & 0.167 & 0.967 \\
\hline \multirow{2}{*}{ VZM } & NSHG & 100 & 0.537 & 0.151 & 0.015 & 0.767 & 0.023 & 0.100 & 0.867 \\
\hline & Total & 200 & 0.565 & 0.151 & 0.011 & 0.833 & 0.023 & 0.100 & 0.933 \\
\hline SKLM & Total & 200 & 0.596 & 0.161 & 0.011 & 0.833 & 0.026 & 0.167 & 1.000 \\
\hline \multirow[t]{3}{*}{ Total } & OSHG & 300 & 0.612 & 0.159 & 0.009 & 0.833 & 0.025 & 0.167 & 1.000 \\
\hline & NSHG & 300 & 0.586 & 0.151 & 0.009 & 0.900 & 0.023 & 0.100 & 1.000 \\
\hline & Total & 600 & 0.599 & 0.155 & 0.006 & 0.900 & 0.024 & 0.100 & 1.000 \\
\hline
\end{tabular}

Source: Computed from primary data.

$S D=$ Standard Deviation $\mathcal{E} S E M=$ Standard Error of Mean

Table 11: Political Empowerment differences between OSHG and NSHG Households

\begin{tabular}{|c|c|c|c|c|}
\hline Measures & VSKP & VZM & SKLM & Total \\
\hline \multicolumn{5}{|c|}{ Panel A: ANOVA Test } \\
\hline \multicolumn{5}{|c|}{$\mathrm{H}_{0}$ : Mean empowerment between OSHG and NSHG is not different } \\
\hline p-value & 0.003 & 0.010 & 0.084 & 0.043 \\
\hline Inference & Rejected $\mathrm{H}_{0}$ & Rejected $\mathrm{H}_{0}$ & Rejected $\mathrm{H}_{0}$ & Rejected $\mathrm{H}_{0}$ \\
\hline \multicolumn{5}{|c|}{ Panel B: Z Test } \\
\hline Z-statistics & $3.026^{*}$ & $2.618^{*}$ & $1.736^{*}$ & $2.029^{*}$ \\
\hline p-value & 0.003 & 0.010 & 0.084 & 0.043 \\
\hline Inference & Rejected $\mathrm{H}_{0}$ & Rejected $\mathrm{H}_{0}$ & Rejected $\mathrm{H}_{0}$ & Rejected $\mathrm{H}_{0}$ \\
\hline
\end{tabular}

Source: Computed from primary data.

Note: Chi-square values significant if p-values less than 0.10 . 
The study shows that an average score political empowerment index for OSHGs was 0.612 while NSHG was 0.586 , it can be concluded that the OSHGs observed better political empowered when compared to NSHGs. In the case of OSHG respondents have lower standard deviation when compared to NSHG respondents thus shows that the OSHG respondents were having higher homogeneity than NSHG respondents. The results of $\mathrm{f}$-test and z-test disclose that there were significant mean variations in political empowerment between OSHGs and NSHGs in all sampled districts (Table 10 \& 11).

\section{CONCLUSION}

According to empowerment index, the highest per cent respondents were highly empowered regarding social indicators. The OSGH respondents were empowered very high and high while NSHG respondents were high empowered. An average score of social empowerment index revealed that hat the OSHGs observed better empowered when compared to NSHGs. Economic empowerment index disclosed that the highest per cent of respondents were empowered less regarding economic indicators. The maximum respondents were empowered less in the case of both the OSHG and NSHG households. According to average score of economic empowerment index, the OSHG households observed better economic empowered when compared to NSHG households. Political empowerment index disclosed that the highest per cent of respondents were empowered less regarding political indicators. The maximum respondents were empowered politically less in the case of both the OSHG and NSHG households. According to average score of political empowerment index, the OSHG households observed better economic empowered when compared to NSHG households.

\section{REFERENCES}

Alemu, S.H., Van Kempen, L., \& Ruben, R. 2018. Women empowerment through self-help groups: The bittersweet fruits of collective apple cultivation in highland Ethiopia. Journal of Human Development and Capabilities, 19(3): 308-330.

Bansal, D. 2010. Impact of Microfinance on Poverty, Employment and Women Empowerment in Rural Punjab. PhD diss., Punjabi University, Patiala.
Brody, C., Hoop, T.D., Vojtkova, M., Warnock, R., Dunbar, M., Murthy, P. and Dworkin, S.L. 2017. Can self-help group programs improve women's empowerment? A systematic review. Journal of Development Effectiveness, 9(1): 15-40.

Dadhich, C.L. 2001. Micro finance-A panacea for poverty alleviation: A case study of oriental Grameen project in India. Indian Journal of Agricultural Economics, 56(3): 419-426.

Duflo, E. 2012. Women empowerment and economic development. Journal of Economic Literature, 50(4): 1051-1079.

Garikipati, S., Johnson, S., Guérin, I. and Szafarz, A. 2017. Microfinance and gender: Issues, challenges and the road ahead. The Journal of Development Studies, 53(5): 641-648.

Girija K.S. 1995. Group approach to empowerment of rural women - IFAD Experience in Tamil Nadu state. BIRD, Lucknow, GOI (1991), Rep. Working group on organizing Self-Help Groups.

Husain, Z., Mukerjee, D. and Dutta, M. 2014. Self-help groups and empowerment of women: self-selection, or actual benefits?. Journal of International Development, 26(4): 422-437.

Jakimow, T. and Kilby, P. 2006. Empowering women: A critique of the blueprint for self-help groups in India. Indian Journal of Gender Studies, 13(3): 375-400.

Kumar, L. 2013. Illusion of women empowerment in microfinance: a case study. Economic and Political Weekly, 48(15): 70-76.

Maurya, R. 2011. Women, microfinance and financial inclusion in India. International Journal of Business Economics and Management Research, 2(7): 61-72.

Mehta, P. and Sharma, K. 2014. Leadership: Determinant of Women Empowerment. SCMS Journal of Indian Management, 11(2): 5-10.

Nanda, Y.C. 1999. Linking banks and self-help groups in India and the role of NGOs: lessons learned and future perspectives. National Banks News Review, 15(3): 1-9.

Pathak, P.A. 1992. Self-Help Groups and their linkages with Banks. National Bank News Review, 7(2): 9-10.

Prasad, B. 2006. Cooperative Sector-Changes Required to Operationally Internalise Concept of Microfinance. The Cooperator, 43(8): 355-59.

Sami, L. 2017. A Study on Women Empowerment through Microfinance in North India. Asia Pacific Journal of Research, 1(48): 146-153.

Sen, A. 2001. Many faces of gender inequality, Frontline, 18(22): 35-39.

World Bank. 2001. Poverty Alleviation Microfinance Project (02) Microfinance II. Washington, DC. 
